\title{
Distribution and eco-coenotic patterns of the forest orchid Epipactis pontica in Slovakia
}

\author{
R. Hrivnák, M. Hrivnák, M. Slezák, J. Vlčko, J. Baltiarová, M. Svitok
}

\begin{abstract}
Hrivnák R., Hrivnák M., Slezák M., Vlčko J., Baltiarová J., Svitok M., 2014. Distribution and eco-coenotic patterns of the forest orchid Epipactis pontica in Slovakia. Ann. For. Res. 57(1): 55-69, 2014.
\end{abstract}

Abstract. The present study is aimed at characterising the ecological niche of a typical forest orchid (Epipactis pontica) in Slovakia. Vegetation-environmental data were collected across mountain ranges and their foothills in the Western Carpathians in 2011. Numerical classification was performed to delimit the main forest vegetation types and a linear mixed effect model was applied to reveal differences between plots with versus without $E$. pontica. This endangered species of Slovak flora grows in thermophilous turkey oak forests (Quercion confertae-cerris), mesophilous broad-leaved mixed oak-hornbeam forests (Carpinion betuli), but most stands correspond to the acidic (Luzulo-Fagion sylvaticae) and mesotrophic beech forests (Fagion sylvaticae). Principal component analysis supported the floristic separation of plant communities and showed some significant vegetationenvironmental relationships. E. pontica prefers forests with closed canopy (mean canopy openness: 8.5-15.1\%) occurring especially on slightly acidic (soil reaction: 4.48-5.65) and nutrient-poor soils (soil conductivity: $43.1-72.6 \mu \mathrm{S} / \mathrm{cm}$ ). The proposed Ellenberg indicator values for light (4), temperature (5), continentality (4), moisture (5), soil reaction (6) and nutrients (5) follow species composition pattern of vascular plants in Slovak phytosociological relevés with E. pontica occurrence. They are also in accordance with its habitat conditions and ecological requirements in other parts of its range. The linear mixed effect model did not confirm any environmental peculiarity of plots with the presence of E. pontica at a microscale level and this result was consistent across the studied sites. Keywords broad-leaved forests, Central Europe, ecological indicator values, endangered species, habitat conditions, Orchidaceae.

Authors. Richard Hrivnák (richard.hrivnak@savba.sk) - Institute of Botany, Slovak Academy of Sciences, Dúbravská cesta 9, SK-845 23 Bratislava, Slovakia; Matúš Hrivnák, Juliána Baltiarová, Marek Svitok - Department of Biology and General Ecology, Faculty of Ecology and Environmental Sciences, Technical University in Zvolen, Masarykova 24, SK-960 53 Zvolen, Slovakia; Michal Slezák, Faculty of Education, Catholic University, Hrabovská cesta 1, SK-034 01 Ružomberok, Slovakia and Institute of Botany, Slovak Academy of Sciences, Dúbravská cesta 9, SK-845 23 Bratislava, Slovakia; Jaroslav Vlčko, Department of Phytology, Faculty of Forestry, Technical University in Zvolen, Masarykova 24, SK-960 53 Zvolen, Slovakia. 
Manuscript received March 14, 2014; revised May 09, 2014; accepted May 16, 2014; online first May 19, 2014.

\section{Introduction}

The orchid family is one of the world's largest groups of flowering plants with almost 25.000 known taxa (Chase et al. 2003). Its distribution range comprises mainly tropical and subtropical regions, with a decline in species diversity in temperate Europe (Delforge 2005). Variation in number of species reported in Europe has usually been attributed to diverse taxonomic treatment and status of local endemic taxa. The same is also true for the genus Epipactis (Tranchida-Lombardo et al. 2011), which consists of a considerably variable group of species in terms of morphology (Hollingsworth et al. 2006).

Epipactis pontica Taubenheim (syn. E. helleborine subsp. pontica (Taubenheim) Sundermann, E. persica subsp. pontica (Taubenheim) $\mathrm{H}$. Baumann et R. Lorenz) is a polycarpic and self-pollinating species belonging to the $E$. helleborine group (Delforge 2005). This terrestrial and typical forest species, with a slim stem and lanceolate to narrow lanceolate leaves, can reach a height of $30 \mathrm{~cm}$. The sparse spike is composed of a few small white-green and most often only slightly open flowers. The distinctive floral morphology is characterised by a widely U-shaped mesochile, a flat hypochile and a pronounced but non-functional rostellum (Taubenheim 1975, Batoušek 2010, Batoušek \& Kežlínek 2012).

Although E. pontica was originally described by Taubenheim (1975) from the Pontic Mountains in the northern part of Turkey, its recent range encompasses predominantly woodlands in the Balkan Peninsula and Central Europe (Delforge 2005, Sulyok \& Molnár 2011). Due to the scarcity and vulnerability of its populations, E. pontica was declared endangered and included in Central European national red lists (e.g. in Hungary - Király 2007, Czech Republic - Grulich 2012). This species is also considered to be endangered in Slovakia (Feráková et al. 2001), where it was first documented by Vlčko (1995) from 10 scattered sites across the Western Carpathians and their foothills. However, an increased number of new localities have been observed in the last two decades (Mered'a 1997, Vlčko et al. 2003).

Distribution, population dynamics and vitality of the orchid species are closely associated with plant-fungal interactions (Rasmussen 1998, Taylor \& Bruns 1999), pollination and seed germination (Rasmussen \& Whigham 1993), but environmental factors and human impact also play important roles (Stuckey 1967, Silvertown et al. 1994, Vallius 2001, Janečková et al. 2006). Similar studies devoted to the genus Epipactis or specifically to the species E. pontica are rare (Ehlers et al. 2002, Jurčák et al. 2005, 2006).

In spite of increasing interest in many aspects of its distribution, morphology and ecology (e.g. Batoušek 1996, Mered’a 1997, Petrova \& Venkova 2006), a complex ecological and coenological study has been lacking. Although biological characteristics represent the most-frequently discussed predictors, our attention focused on environmental requirements and coenotic preference of E. pontica in Slovakia. The present autecological study could thus provide relevant information necessary for understanding its rarity and effective conservation. We expected that environmental variables affecting large-scale distribution patterns of E. pontica would also be predictors of its occurrence at the microscale level. Explanatory variables were selected according to current knowledge of the species`s ecological preferences.

The aims of the present paper were: (i) to summarise all available distribution data of the 
species in Slovakia, (ii) to characterise the floristic composition of sites with $E$. pontica in Slovakia, (iii) to assess the environmental conditions that are suitable for the occurrence of the species at the microscale level in selected sites in Slovakia.

\section{Methods}

\section{Field sampling}

The distribution pattern of E. pontica in Slovakia was compiled using available literature sources and original unpublished data (Fig. 1, Electronic supporting information). In order to cover a wide variety of environmental conditions, seven sampling sites with sufficiently large $E$. pontica populations were chosen for detailed ecological research in 2011 (Electronic supporting information, Fig. 1). Ten circular sampling plots $\left(0.5 \mathrm{~m}^{2}\right)$ without $E$. pontica were randomly selected within each sampling site. Subsequently, the closest specimens of $E$. pontica to each of those plots were found and paired plots of the same size were established around those specimens. Pairs of plots with and without $E$. pontica were treated as matched pairs. A total of 140 plots (7 sites $\times$ 10 matched-pair plots) were sampled for environmental characteristics that could affect the incidence of $E$. pontica. One phytosociological relevé with a uniform plot size of $400 \mathrm{~m}^{2}$ (hereinafter called relevé site) was sampled at each site in accordance with the Zürrich-Montpellier approach using the modified nine-degree Braun-Blanquet cover/abundance sampling scale (Barkman et al. 1964).

Geographical coordinates (WGS-84), altitude and aspect were measured using a handheld GPS (Garmin GPSmap 60 CSx) and slope with the Suunto PM-5/1520PC clinometer on relevé sites and plots. Climatic characteristics of sampling sites (Electronic supporting information) were obtained from Miklós (2002). Microrelief shape (concave, convex, flat), per-

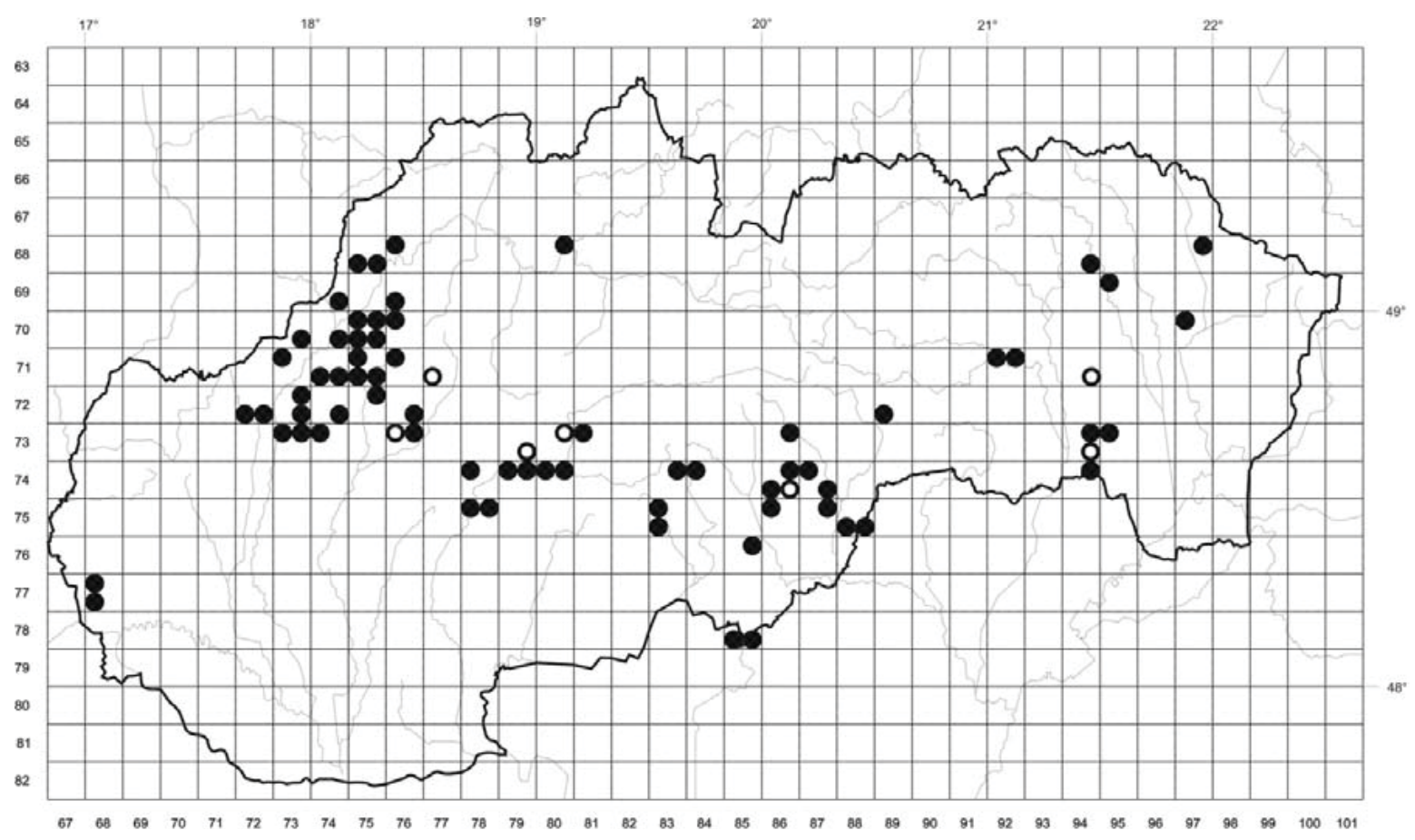

Figure 1 Distribution map of Epipactis pontica in Slovakia. Empty circles represent the sampling sites chosen for the present study. From left to right: n. 5 -Skačany; n. 4 -Kanianka; n. 2 -Budča; n. 3 - Vlkanová; n. 1 - Španie Pole; n. 6 - Herlany (upper) and n. 7 - Rákoš (lower) 
centage cover of the moss layer (incl. lichens; $\left.\mathrm{E}_{0}\right)$, herb layer $\left(\mathrm{E}_{1}\right)$, stones, bare soil, woody litter and other undecomposed dead biomass were visually estimated in plots. Depth of the litter layer was measured at 10 random places within each plot. Soil samples were taken from three random locations within each plot from the uppermost mineral horizon $(8-15 \mathrm{~cm}$, litter removed) in order to reduce soil heterogeneity. Light conditions were assessed from hemispherical photographs taken within the plots. A Nikon Coolpix 5400 digital camera equipped with a fisheye converter FC-E9 was used.

\section{Laboratory and data analysis}

Species affinity to the occurrence of E. pontica was derived from presence/absence data of all vascular plants, which were recorded in four quadrants within the plots. Relevé sites and plots were stored in the TURBOVEG database software (Hennekens \& Schaminée 2001) and exported into the JUICE program (Tichý 2002). Numerical classification of the available phytosociological material (23 relevé sites) was done in the PC-ORD program (McCune \& Mefford 1999) using Sørensen's distance as a measure of dissimilarity and the Beta flexible linkage method $(\beta=-0.25)$ with the logarithmic transformation of species abundance values. The optimal number of clusters was determined using the crispness curve method (Botta-Dukát et al. 2005). Diagnostic species were determined based on the combined concept of fidelity ( $\Phi-$ phi coefficient; Chytrý et al. 2002) and frequency. Diagnostic species were those with $\Phi>0.3$ and significant occurrence in a particular cluster (tested by Fisher's exact test at $p<0.05$ ), frequency within cluster of $>50 \%$ and difference of frequencies among clusters of more than $40 \%$. Before the analysis, several narrowly delimited species or taxonomically complicated ones were united into aggregate taxa or genus level: Crataegus sp. (C. monogyna, Crataegus. sp.), Galeopsis sp. (Galeopsis. sp., G. speciosa, G. tetrahit),
Pulmonaria officinalis agg. (P. obscura, $P$. officinalis), Rosa sp. (R. canina agg., Rosa sp.). The species-environment relationship was assessed by principal component analysis (PCA) in the Canoco for Windows package (ter Braak \& Šmilauer 2002), as the length of the DCA (detrended correspondence analysis) gradient was 2.69 units. Unweighted Ellenberg's indicator values of vascular plants (EIV; Ellenberg et al. 1992) were used as supplementary environmental variables to explain major variation patterns in the floristic composition. Species abundance values were logarithmically transformed. Correlations between EIVs of individual relevés and relevé scores on the first three ordination axes were assessed by the Spearman's correlation coefficient using STATISTICA software (StatSoft 2001).

Soil samples were air-dried at laboratory temperature, crushed and passed through a $2 \mathrm{~mm}$ sieve. Soil $\mathrm{pH}$ and conductivity were measured in a distilled-water suspension (soil/ water ratio of $1 / 5$ ) using a $\mathrm{pH} /$ conductivity meter (WTW pH/Cond 340i). Canopy openness expressing the percentage of open sky seen from beneath the forest canopy was calculated with the Gap Light Analyser 2.0 program (Frazer et al. 1999). Slope and aspect were used to calculate the xericity index following the equation proposed by Austin et al. (1984). Mean and standard devation (sd) of litter depth were calculated from field measurements. All parameters of sampling sites were derived from data obtained in plots with the presence of E. pontica. Environmental data recorded at plot level were treated in a partly nested splitplot design and fitted to a linear mixed effect model of the form:

$$
\begin{aligned}
& Y=\text { site }+ \text { matched-pair plot }(\text { site })+\text { plot }+ \text { plot } \\
& \times \text { site }+ \text { plot } \times \text { matched-pair plot }(\text { site })
\end{aligned}
$$

where site, matched-pair plot(site) and interactions are factors with random effects, while plot is a factor with a fixed effect testing for differences between plots with and 
without E. pontica. Response variable $Y$ is a matrix of 15 environmental variables by 140 plots. Prior to analysis, environmental variables were standardised to minimize the effects of different units of measurement. The model was analysed using permutational multivariate analysis of variance (perMANOVA; Anderson 2001) with Euclidean distance as a dissimilarity measure, an approach analogous to redundancy analysis on a correlation matrix (RDA). The results were visualised as a RDA ordination diagram. Probability values were based on 9999 permutations of the original data. Analyses were performed using DISTLM v.5 (Anderson 2004) and R software (R Development Core Team 2011).

\section{Nomenclature}

Nomenclature of vascular plants follows the checklist by Marhold \& Hindák (1998), and the names of plant communities and their syntaxonomical position are in accordance with Jarolímek \& Šibík (2008).

\section{Results}

\section{Distribution in Slovakia}

The current known distribution of E. pontica in Slovakia comprises 120 sites which are primarily situated in the submontane belt of the central and western part of the Carpathian mountain ranges and the north-eastern edge of the Pannonian Basin (Fig. 1). Its occurrence becomes rarer towards the north regions with some isolated localities in north-eastern Slovakia, while records from the south lowland regions and Inner Carpathians basins are still missing. The largest number of sites (31) are reported from the Strážovské and Súl'ovské vrchy Mts, followed by the Slovenské rudohorie Mts (15), Biele Karpaty Mts (13) and the Považský Inovec Mts (12). Their altitudinal range is between $200 \mathrm{~m}$ and $820 \mathrm{~m}$ a.s.l. A detailed overview of sites is presented in the electronic supporting information.

\section{Species composition and vegetation patterns}

Sessile oak (Quercus petraea agg.) was identified as the most common species and was documented in more than $50 \%$ of plots with the presence of $E$. pontica and was also the only species found in all studied sampling sites. Other frequent species in the plots were Carpinus betulus (34\%), Fagus sylvatica (33\%) and Carex pilosa (29\%). The calculation performed on 23 relevé sites provided similar results, where Fagus sylvatica (presence in $96 \%$ sites), Quercus petraea agg. (96\%), Carpinus betulus $(83 \%)$ and Galium odoratum $(70 \%)$ were the most frequently co-occurring species.

Differences in species composition within matched-pair plots were found only in sampling site no. 3 (Vlkanová), with only Carpinus betulus showing a positive fidelity to $E$. pontica $(\Phi=0.524, p<0.05)$.

Numerical classification divided phytosociological relevés into 4 clusters showing obvious floristic variation (Table 1).

Cluster 1 included rather heterogeneous and species-poor stands (12 species per relevé) with low herb layer cover (8-25\%). The monodominant tree layer was composed by Fagus sylvatica, whereas species composition of the forest understorey had a conspicuous mosaic structure. This cluster represents a transition between beech-dominated vegetation that corresponded to either mesotrophic canopy-closed beech forests of the association Dentario bulbiferae-Fagetum (alliance Fagion sylvaticae) or acidophilous beech forests of the association Luzulo nemorosae-Fagetum (alliance LuzuloFagion sylvaticae).

The physiognomy of the forest overstorey in cluster 2 was determined by dominant Quercus petraea agg. with a constant admixture of Carpinus betulus and Fagus sylvatica. This well-differentiated forest vegetation (incl. Astragalus glycyphyllos, Galium schultesii, Hi- 
Table 1 Shortened synoptic table of forest vegetation with presence of Epipactis pontica showing the frequency and abundance range (as superscripts) of each plant taxa. Only those taxa with occurrence in at least three relevés are shown. They were arranged according to decreasing fidelity to one of the four clusters

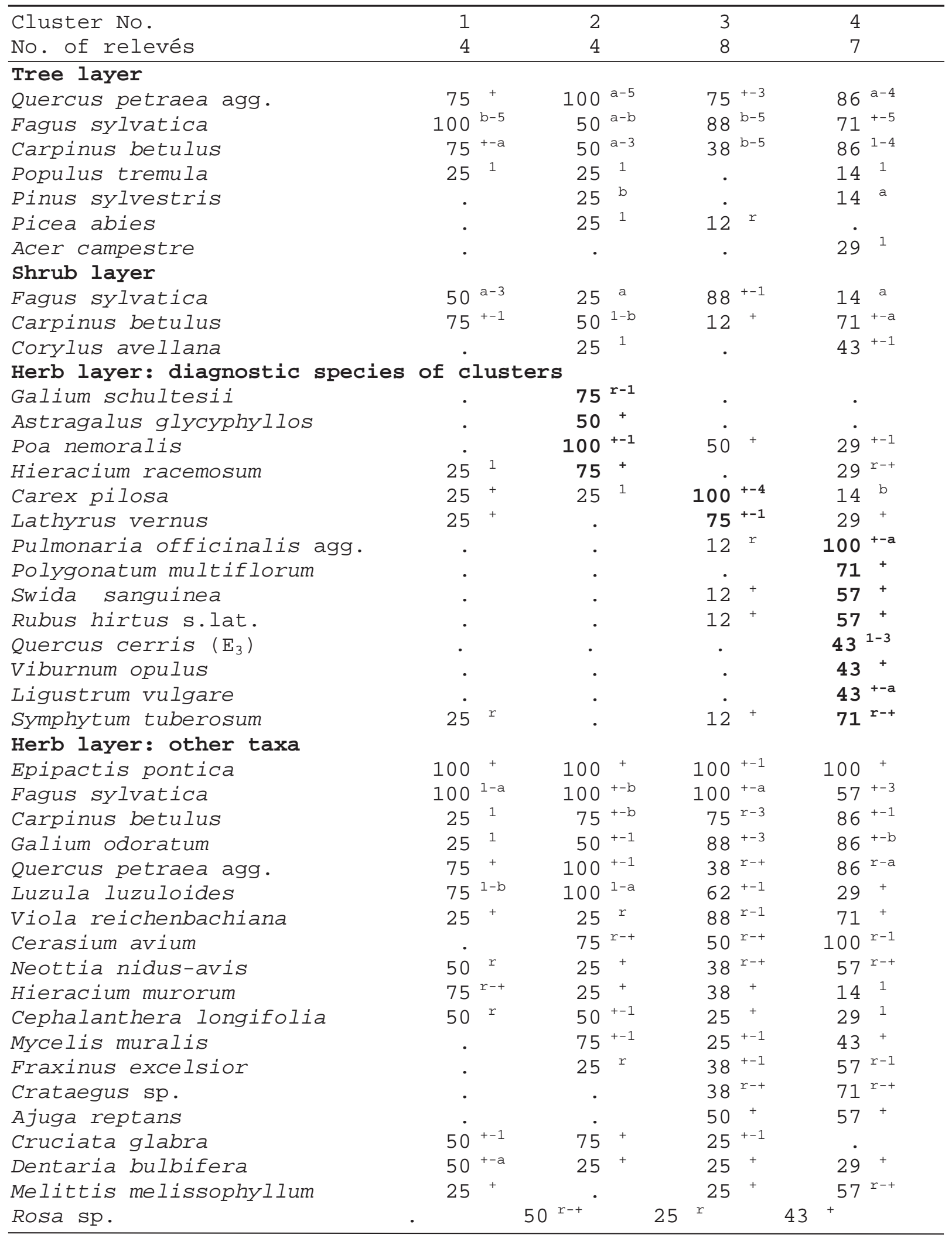

60 
Table 1 (continued)

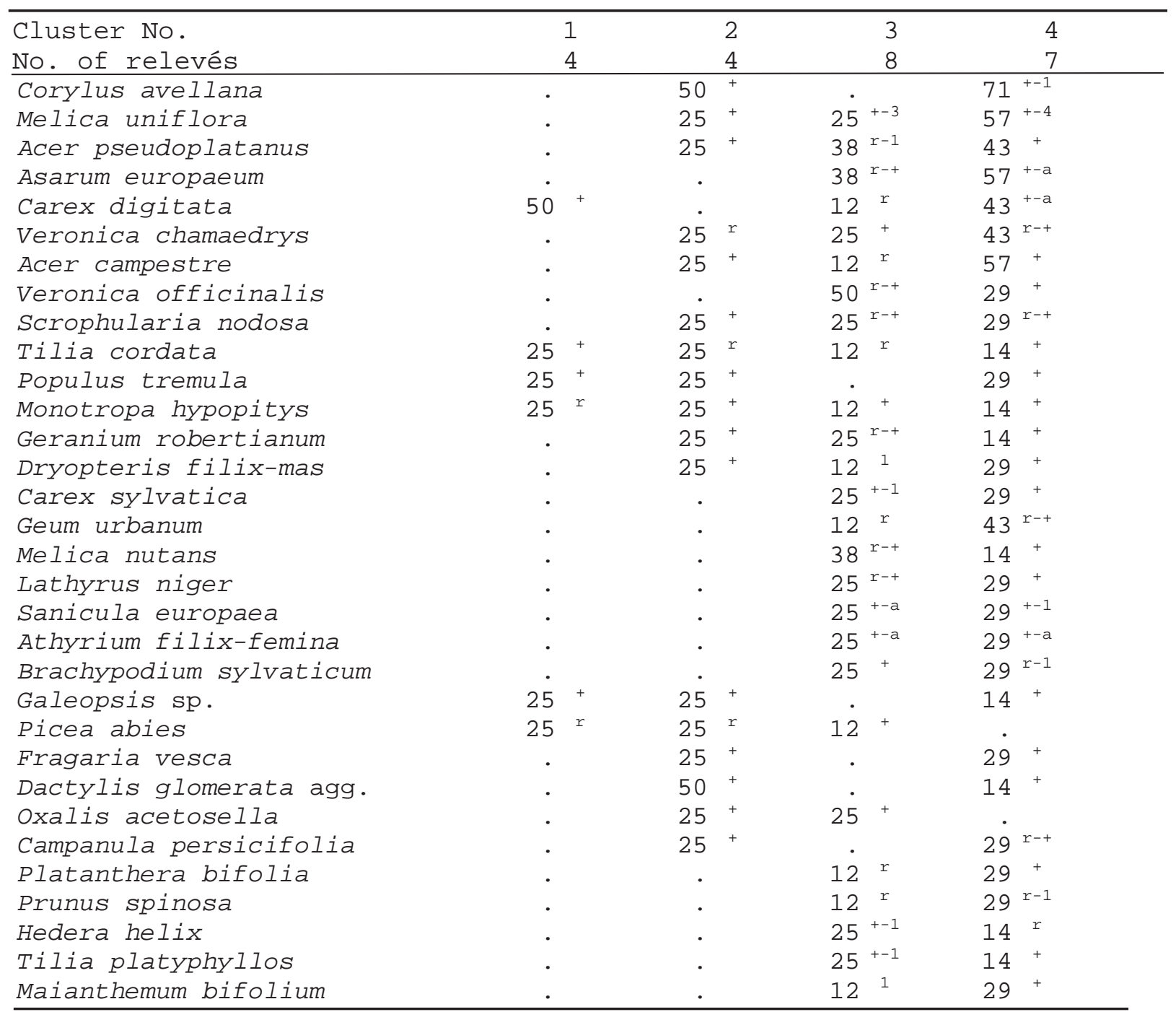

Note. List of phytosociological relevés in each cluster. Cluster 1: Hrivnák (1997) - 4 relevés; Cluster 2: Author's original (unpublished) - 2 rels., Vlčko (1996) - 2 rels.; Cluster 3: Author's original (unpublished) - 3 rels., Hrivnák (1997) - 1 rel., Mered’a (1997) - 2 rels., Špalková (2000) - 1 rel., Vlčko (1996) - 1 rel., Cluster 4: Author's original (unpublished) - 3 rels., Perný \& Mered’a (2000) - 1 rel., Vlčko (1996) - 3 rels.

eracium racemosum, Poa nemoralis) showed close syntaxonomical affiliation to the association Poo nemoralis-Quercetum dalechampii (alliance Quercion confertae-cerris).

While broad-leaved trees (Fagus sylvatica, Carpinus betulus and Quercus petraea agg.) alternated as the dominant species in the tree layer of the stands in cluster 3 , the floristic composition of the understorey was driven mainly by mesic species (e.g. Carex pilosa, Lathyrus vernus). This cluster merged Carpathian sedge oak-hornbeam forests of the Carici pilosae-
Carpinetum (alliance Carpinion betuli) and beech forests of the Carici pilosae-Fagetum (alliance Fagion sylvaticae).

Cluster 4 included three-layered stands, where dominant Quercus petraea agg. in the tree layer was constantly accompanied by Carpinus betulus, Fagus sylvatica and Quercus cerris. The typical grassy aspect of the speciesrich herb layer resulted from the prevalence of Melica uniflora. An abundant mesic herbs (e.g. Polygonatum multiflorum, Pulmonaria officinalis agg., Symphytum tuberosum) supported 


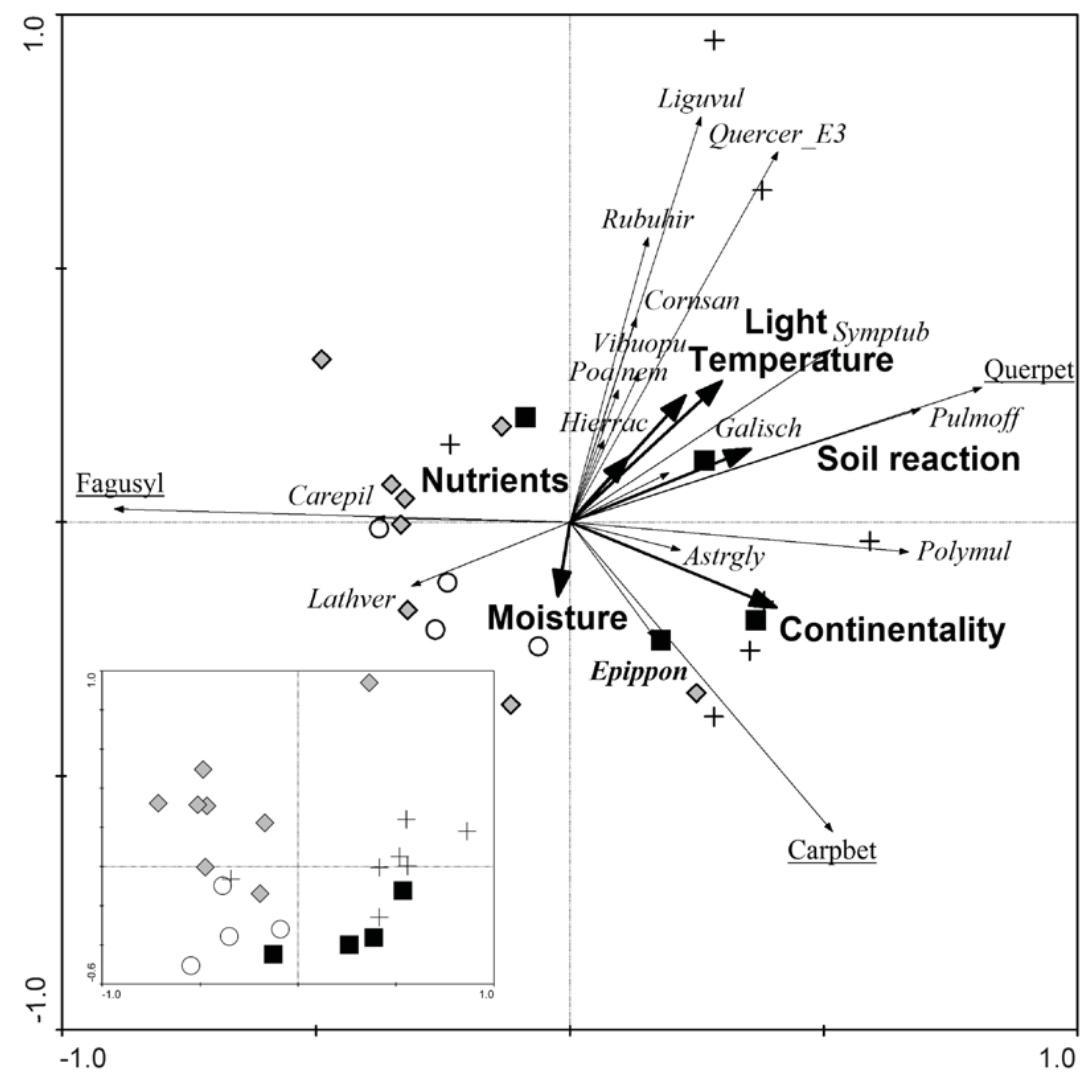

Figure 2 PCA ordination diagram of 23 forest relevé sites with Epipactis pontica (empty circles - cluster 1, black squares - cluster 2 , shaded diamonds - cluster 3 , crosses - cluster 4) and passive projection of Ellenberg indicator values. Position of the relevé sites on the first and the third axes is given in the lower part of the figure. Only diagnostic species for individual clusters (in italics, see Table 1), the dominant tree species (underlined) and E. pontica (bold italic) are shown (Astrgly - Astragalus glycyphyllos, Carepil - Carex pilosa, Carpbet - Carpinus betulus, Cornsan - Swida sanguinea, Epippon - Epipactis pontica, Fagusyl - Fagus sylvatica, Galisch - Galium schultesii, Hierrac - Hieracium racemosum, Lathver - Lathyrus vernus, Liguvul - Ligustrum vulgare, Poa nem - Poa nemoralis, Polymul - Polygonatum multiflorum, Pulmoff - Pulmonaria officinalis agg., Quercer_E3 - Quercus cerris in the tree layer, Querpet - Quercus petraea agg., Rubuhir - Rubus hirtus s.lat., Symptub - Symphytum tuberosum, Vibuopu - Viburnum opulus)

its assignment to the Melico uniflorae-Quercetum petraeae (alliance Carpinion betuli).

PCA ordination showed relatively good floristic differentiation of plant communities, mainly when the first and third axes were displayed (Fig. 2). While the correlations between all EIVs and the first two PCA ordination axes were statistically non-significant ( $p$ $>0.05$; Spearman's correlation coefficients ranged from -0.30 to 0.37 ), EIV for nutrients $(r=0.63)$ and moisture $(r=0.55)$ were significantly correlated $(p<0.01)$ with the third PCA axis.

\section{Ecological preferences}

Analysis of the habitat conditions allowed us partially to characterise the niche of E. pontica (Fig. 3). This orchid appears to be a shade-tolerant species preferring canopy-closed forest vegetation on strongly to moderately acidic soils ( $\mathrm{pH} 4.48-5.65)$. Low content of soluble mineral nutrients in soil solution, indicated by a mean value of soil conductivity of 52.6 $\mu \mathrm{S} / \mathrm{cm}$, pointed towards its affinity to nutrient-poor soil substrates. It was found primarily in habitats with a flat microrelief $(71 \%$ of 
A)

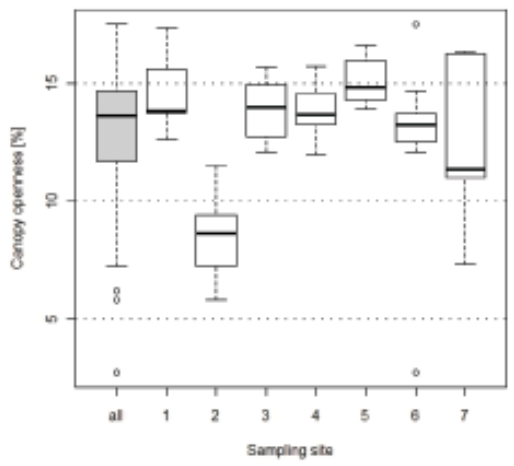

C)

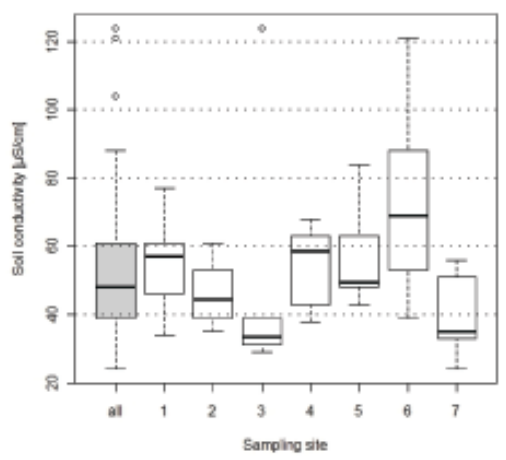

E)

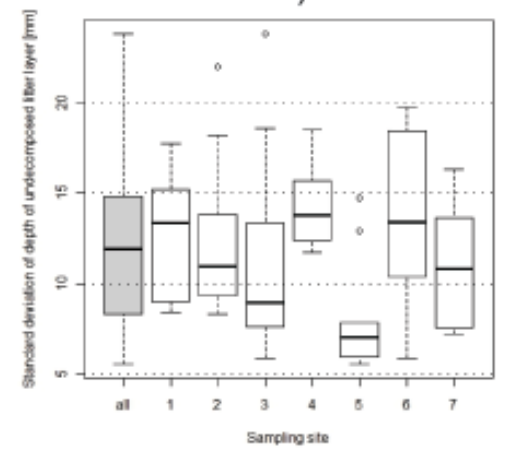

B)

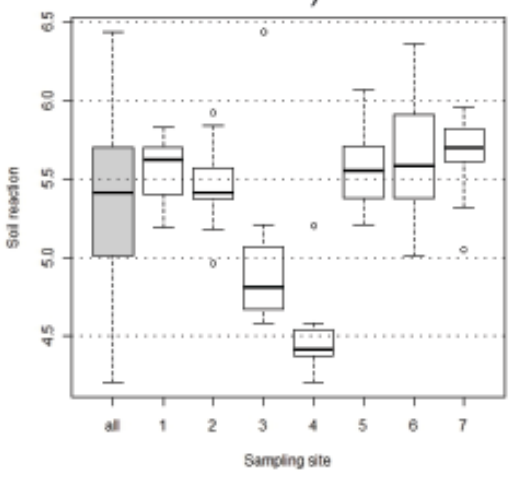

D)

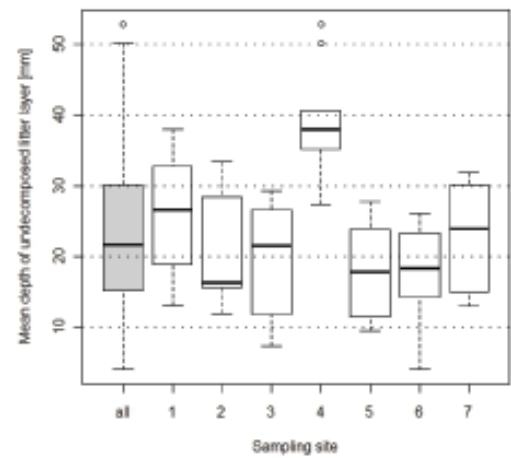

F)

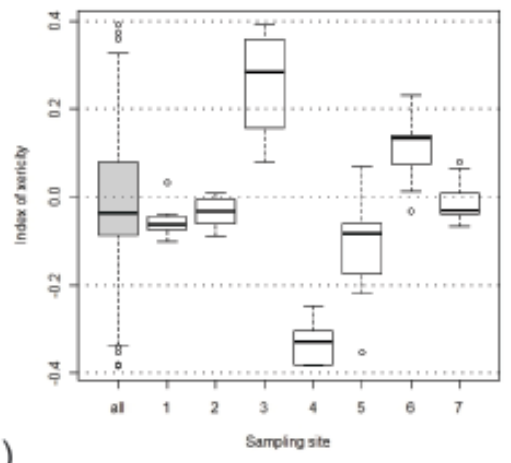

G)

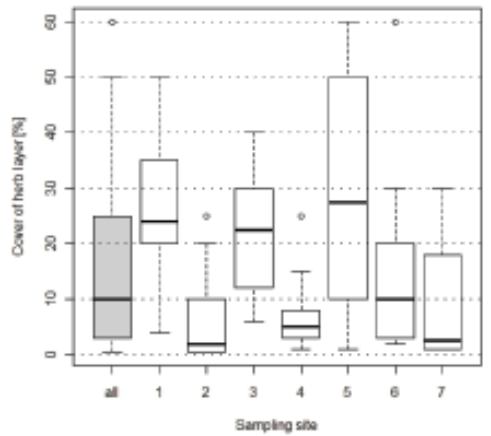

Figure 3 Box-and-whiskers plots of the canopy openness (A), soil reaction (B), soil conductivity (C), depth of undecomposed litter layer (D), standard deviation of depth of undecomposed litter layer (E), index of xericity $(F)$ and cover of herb layer $(G)$ in the sampling sites. The central line of each box refers to the mean value, boxes to the lower $(25 \%)$ and upper (75\%) quartiles, and whiskers to the range of values (minimum and maximum). Legend: all - data from all sampling sites put together; 1 - Španie Pole; 2 - Budča; 3 - Vlkanová; 4 - Kanianka; 5 - Skačany; 6 - Herl'any; 7 - Rákoš 
all plots) and with relatively uniform (except for the Kanianka sampling site) depth of undecomposed litter layer $(23 \mathrm{~mm})$. They showed different slopes and aspects following a high variation in xericity index. The obvious affiliation of $E$. pontica to a less-developed herb layer (with the cover from $8 \%$ to $28 \%$ ) suggests that the species has a low competitive ability. The mean values of the remaining environmental factors were as follows: cover of the moss layer $(0.3 \%)$, rocks $(0.5 \%)$, wood litter $(3.3 \%)$, bare soil $(4.8 \%)$ and undecomposed phytomass without woody material (94\%).

Calculation of EIVs from the Slovak phytosociological relevé sites (Table 1) led to the following mean values of habitats with $E$. pontica: light $=4.46$, temperature $=5.44$, continentality $=3.53$, moisture $=4.95$, soil reaction $=6.10$ and nutrients $=4.99$. To conclude, $E$. pontica is a shade-demanding to shade tolerant species (proposed EIV light 4), occurring mainly in regions with a sub-oceanic climate, mostly in Central Europe, but spreading towards the East (EIV continentality 4). The species is an indicator of moderately acidic to slightly basic fresh soils (EIV soil reaction 6) with a moderate dampness (EIV moisture 5), and sites with an intermediate fertility (EIV nutrients 5) and with moderate average temperatures (EIV temperature 5).

In spite of this relatively well-defined habitat preferences and statistically significant differences among sites, we did not find significant differences in environmental characteristics between plots with versus without $E$. pontica (Table 2). This trend was consistent for all sampling sites (non-significant plot by site interaction) and was also apparent from the RDA ordination which accounted for $29 \%$ of variability in the environmental data (Fig. 4).

\section{Discussion}

The present study revealed considerable floristic variability of forest understoreys with presence of Epipactis pontica in Slovakia. Although the first records of the orchid were reported from mesophilous broad-leaved mixed oak-hornbeam forests of the Carpinion betuli alliance and recently from the thermophilous turkey oak forests (Quercion confertae-cerris), the species occurred mainly in the herb layer of acidic and mesotrophic beech forests ( $\mathrm{Luzu}$ lo-Fagion sylvaticae and Fagion sylvaticae). These findings are in agreement with both, the maps of real and potential forest vegetation (Fig. 5A-B) and the main outcomes of some previous studies (e.g. Vlčko et al. 2003).

The overall range of the species is partially disjunct, with some outlying localities in northern Turkey (Delforge 2005). However, the floristic and habitat differences across this broad scale territory did not strongly modify the coenotic preference of E. pontica for beechdominated stands. Such vegetation affinity has already been pointed out in the Central Europe (Presser 2002, Batoušek 2010, Sulyok \& Molnár 2011) and the Balkan Peninsula (Petrova \& Venkova 2006, Tsiftsis et al. 2008). In addition, this orchid has been also found in the oriental beech (Fagus orientalis Lipsky) forests

Table 2 Results of perMANOVA testing for the differences in environmental characteristics between sites, matched-pair plots and plots with presence and absence of $E$. pontica (DF - degrees of freedom; MS - mean square; pseudo- $F$ - test criterion; $p$ - probability based on 9999 permutations)

\begin{tabular}{llllc}
\hline Source of variability & DF & MS & pseudo- $F$ & $p$ \\
\hline site & 6 & 102.3 & 8.78 & 0.0001 \\
matched-pair plot (site) & 63 & 11.6 &. &. \\
plot & 1 & 11.9 & 0.98 & 0.4745 \\
plot $\times$ site & 6 & 12.1 & 1.17 & 0.1768 \\
plot $\times$ matched-pair plot (site) & 63 & 10.4 &. &. \\
\hline
\end{tabular}



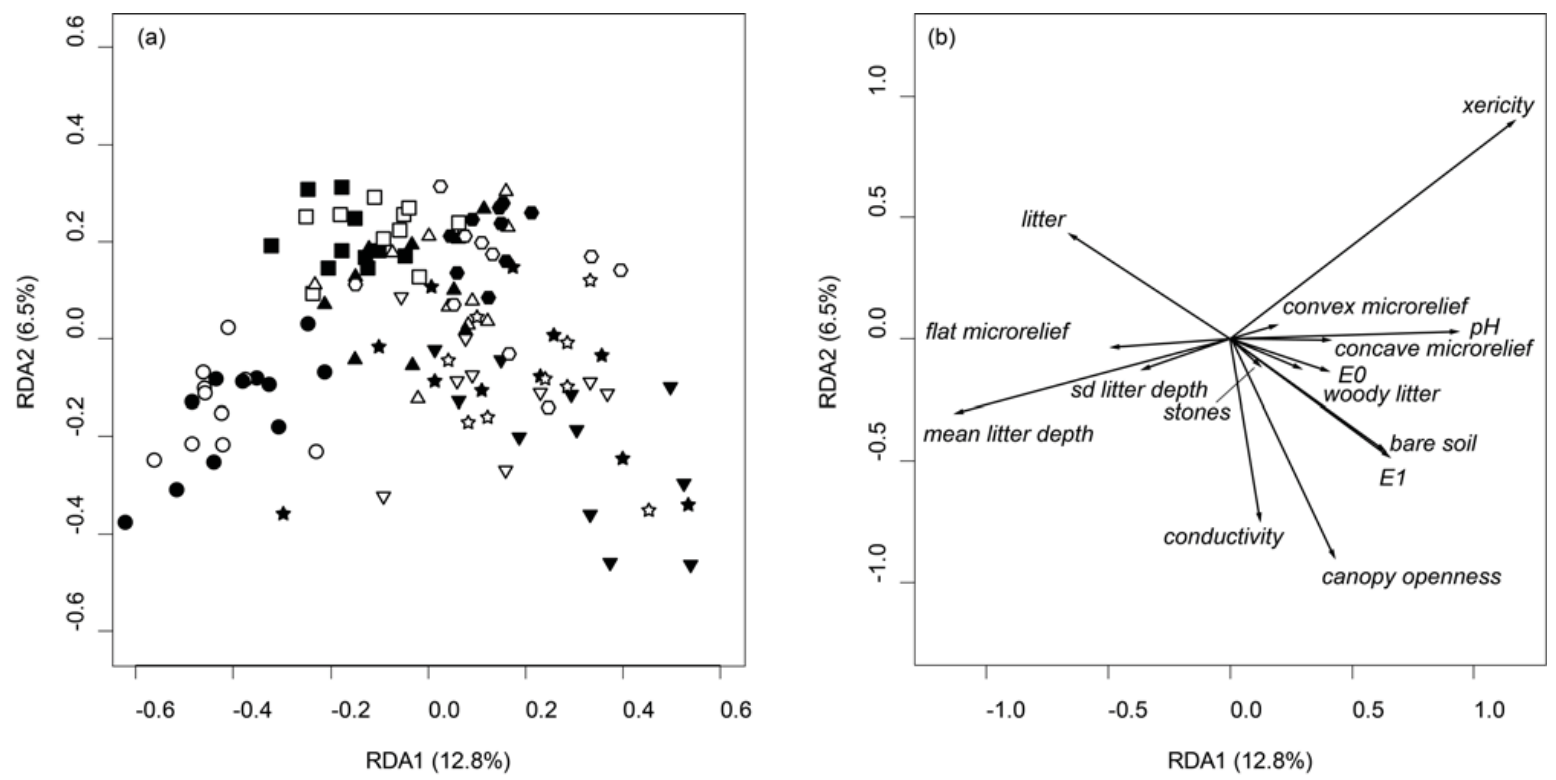

Figure $4 \mathrm{RDA}$ ordination diagrams representing differences in environmental characteristics between sites (different symbols) and plots with presence (full symbols) and absence (empty symbols) of $E$. pontica (a). Vectors of environmental characteristics are displayed (b). Scaling of diagrams is focused on plot distances (a) and correlations of environmental variables (b), respectively. Variances explained by the first two RDA axes are given in parentheses. Abbreviations of environmental variables are explained in the Methods section

(Taubenheim 1975).

Previous studies revealed the light conditions and soil nutrient-related variables (e.g. soil $\mathrm{pH}$, organic matter) as important drivers for potential establishment, growth and distribution of E. pontica. Although its populations may occasionally permeate into canopy-closed forest edge vegetation (Taubenheim 1975), there are no field observations of occurrence in treeless (i.e. herbaceous) vegetation. This orchid is thus considered to be a typical forest and shade-tolerant herb (Delforge 2005, Baumann et al. 2006) rare in woodlands with a more open canopy (Presser 2002). Similar light preferences have already been estimated for Slovak populations (Vlčko 1996, Mered'a 1997) and our results are in accordance with them. Whereas there is good agreement on the light requirements of E. pontica in the scientific literature, the importance of the soil acidity gradient seems to be still vague and partially inconsistent. Several authors (e.g. Timpe \& Mrkvicka 1996) consider the species to be either calcicolous or preferring nutrient-rich and calcareous sites with neutral to basic soil reaction (Taubenheim 1975, Presser 2002, Sulyok \& Molnár 2011). On the other hand, an increasing number of localities on acidic soils have been reported recently (e.g. Vlčko et al. 2003, Petrova \& Venkova 2006, Tsiftsis et al. 2008). All studied sampling sites in Slovakia showed strongly to slightly acidic soil $\mathrm{pH}$ (Fig. 5C), as well. Yet, this pattern cannot be generalised, as Mered'a (1997) found the species on slightly basic sites as well. These findings, together with the published information from the whole distribution area (Delforge 2005), clearly suggest that E. pontica is a widely $\mathrm{pH}$-tolerant species, and thus the soil characteristics play only a minor role in limiting its occurrence. However, the poor availability of particular nutrients and aluminium toxicity on very acidic soils represent substantial physiological constraint for many vascular plants (Tyler 2003), which may be a possible explanation of low species richness and herb- 

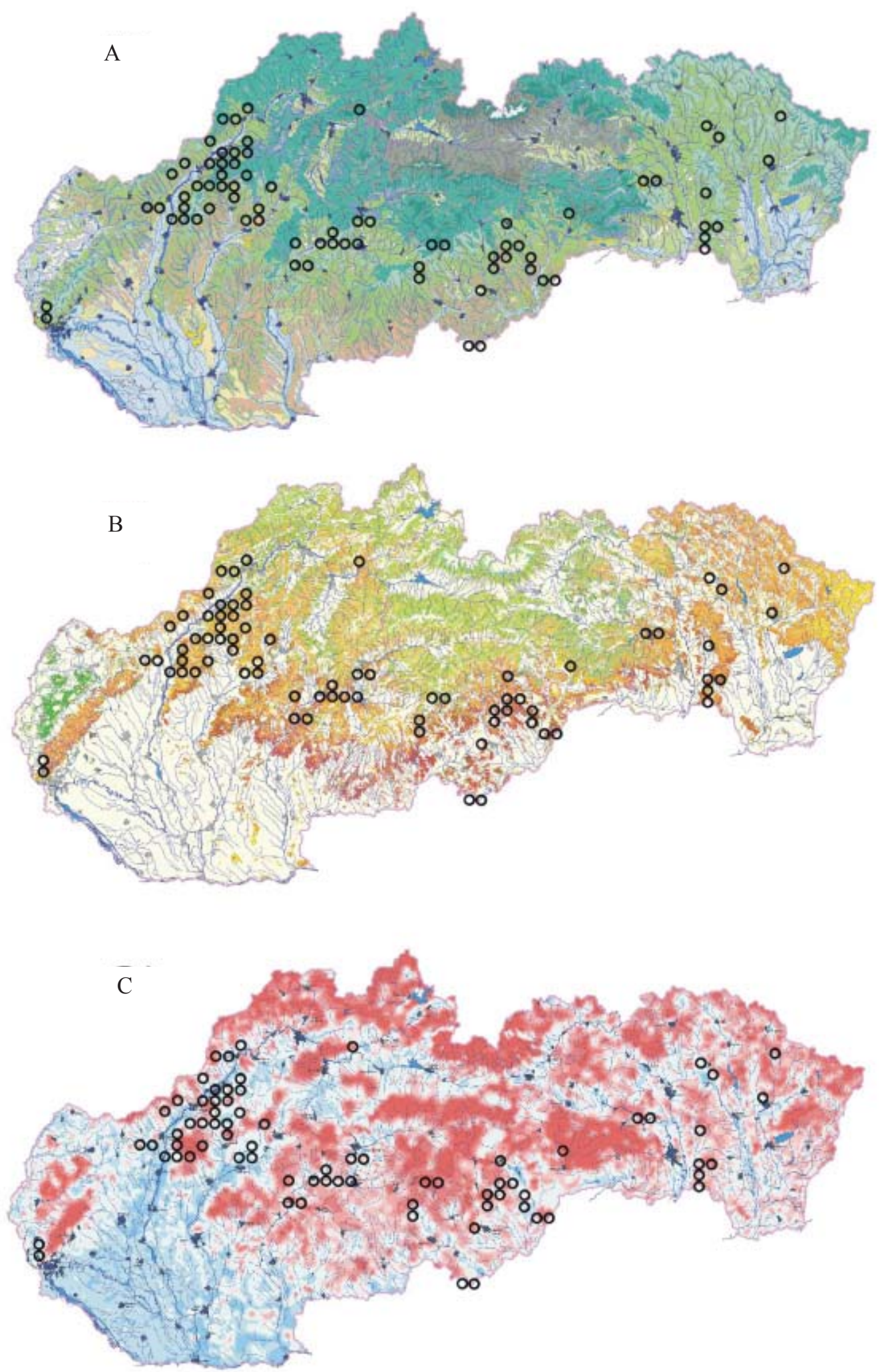

Figure 5 Distribution of Epipatis pontica in Slovakia: A) potential natural vegetation (shades of green - oakhornbeam forests; shades of yellow and pink - oak forests; shades of blue-green - beech forests; for other colours see Miklós 2002), B) tree species composition of forests (red - Quercus cerris; dark brown - Quercus spec. div.; dark pink - Carpinus betulus; light brown - Fagus sylvatica; for other colours see Miklós 2002) and C) soil reaction (pH increases from dark blue, light blue, light red to dark red) 
layer cover in such habitats. In addition, the high competitive ability of the forest overstorey is able to suppress the development of the understorey layer. If the close relationship of E. pontica to European beech stands is taken into account, there might be several mutually non-exclusive mechanisms responsible for this pattern including competition for light, uptake of soil resources and production of slowly decomposing leaf litter (Ellenberg 2009, Packham et al. 2012).

Environmental determinants affecting the distribution pattern of E. pontica appear to be scale-dependent. Soil parameters and also partially light availability can most likely determine its occurrence across geographically large areas, but their importance gradually decreases towards local scales. Biological characteristics, such as root mycorrhiza, interspecific competition, allelopathy and underground growth, together with a complex of additional environmental factors, become more relevant at the micro-site level (e.g. Jurčák et al. 2006, Tsiftsis et al. 2008, Jakubska-Busse et al. 2009).

\section{Conclusions}

Epipactis pontica is a forest orchid found on 120 sites in Slovakia with the highest density of the localities in the central part of the Western Slovakia (Strážovské vrchy Mts). Except for hygrophilous forest communities, the species occurs in almost every type of broad-leaved forest. On the other hand, its preference for shaded, beech-dominated forests with a low to moderate cover of understorey vegetation and slightly acidic soils is evident even though the species showed a wide niche in terms of soil acidity.

\section{Acknowledgements}

We would like to thank P. Mered'a Jr. for identifying some Epipactis specimens and making valuable comments on the manuscript, and also O. Tavoda for preparing the distribution map. The study was supported by Slovak Grant Agency for Science VEGA, grants No. 2/0059/11 (60\%), No. 1/0362/13 (30\%) and No. $2 / 0027 / 13(10 \%)$.

\section{References}

Anderson M.J., 2001. A new method for non-parametric multivariate analysis of variance. Austral Ecology 26: 32-46.

Anderson M.J., 2004. DISTLM v.5: a FORTRAN computer program to calculate a distance based multivariate analysis for a linear model. Department of Statistics, University of Auckland, New Zealand, $10 \mathrm{p}$.

Austin M.P., Cunningham R.B., Fleming P.N., 1984. New approaches to direct gradient analysis using environmental scalars and statistical curve-fitting procedures. Vegetatio 55: 11-27. DOI: 10.1007/BF00039976.

Barkman J.J., Doing H., Segal S., 1964. Kritische Bemerkungen und Vorschläge zur quantitativen Vegetationsanalyse. [Critical remarks and suggestions for the quantitative analysis of vegetation]. Acta Botanica Neerlandica 13: 394-419. DOI: 10.1111/j.14388677.1964.tb00164.x.

Baumann H., Künkele S., Lorenz R., 2006. Orchideen Europas - Mit angrenzenden Gebieten [Orchids of Europe with adjacent areas]. Eugen Ulmer KG, Stuttgart, 333 p.

Batoušek P., 1996. Epipactis pontica Taubenheim - nový druh květeny České republiky a Epipactis albensis Nováková et Rydlo - nový druh květeny Bílých Karpat [Epipactis pontica Taubenheim, a new species of flora of the Czech Republic, and Epipactis albensis Nováková et Rydlo, a new species of flora of the Bílé Karpaty Mts]. Sborník Př́rodovědného Klubu v Uherském Hradišti 1: 12-17.

Batoušek P., 2010. Epipactis Zinn - kruštík [Epipactis Zinn - Helleborine]. In: Chrtek J. jun., Kaplan Z., Štěpánková J. (eds), Květena České republiky 8. Academia, Praha, pp. 439-464.

Batoušek P., Kežlínek K., 2012. Kruštíky České republiky [Helleborine of Czech Republic]. ČSOP ZO Hořepník, Prostějov, 56 pp.

Botta-Dukát Z., Chytrý M., Hájková P., Havlová M., 2005. Vegetation of lowland wet meadows along a climatic continentality gradient in Central Europe. Preslia 77: 89-111.

Chase W.M., Cameron M.K., Barrett L.R., Freudenstein V.J., 2003: DNA data and Orchidaceae systematics: a new phylogenetic classification. In: Dixon K.W., Kell S.P., Barrett R.L., Cribb P.J. (eds), Orchid Conservation. Natural History Publications, Kota Kinabalu, Sabah, pp. 69-89. 
Chytrý M., Tichý M., Holt J., Botta-Dukát Z., 2002. Determination of diagnostic species with statistical fidelity measures. Journal of Vegetation Science 13: 79-90. DOI: 10.1111/j.1654-1103.2002.tb02025.x.

Delforge P., 2005. Guide des Orchidées d'Europe, d'Afrique du Nord et du Proche-Orient [Guide to Orchids of Europe, North Africa and the Middle East]. Delachaux \& Niestlé, Lausanne, Paris, 640 p.

Ehlers B.K., Olesen J.M., Ågren J., 2002. Floral morphology and reproductive success in the orchid Epipactis helleborine: regional and local across-habitat variation. Plant Systematics and Evolution 236: 19-32. DOI: 10.1007/s00606-002-0197-x.

Ellenberg H., 2009. Vegetation ecology of central Europe. Cambridge University Press, Cambridge, 734 p.

Ellenberg H., Weber H.E., Düll R., Wirth W., Werner W., Paulissen D., 1992. Zeigerwerte von Pflanzen in Mitteleuropa $\left(2^{\text {nd }}\right.$ ed.) [Indicator values for plant in Central Europe]. Scripta Geobotanica 18: 1-258.

Feráková V., Maglocký Š., Marhold K., 2001. Červený zoznam paprad'orastov a semenných rastlín Slovenska (december 2001) [Red list of ferns and flowering plants of Slovakia (December 2001)]. Ochrana Prírody 20 (Suppl.): 48-81.

Frazer G.W., Canham C.D., Lertzman K.P., 1999. Gap Light Analyzer (GLA): Imaging software to extract canopy structure and gap light transmission indices from tru-colors fisheye photographs. User manual and program documentation. Simon Freiser University, Burnaby and the Institute Ecosystems Studies, Millbrook, $40 \mathrm{p}$.

Grulich V., 2012. Red List of vascular plants of the Czech Republic: 3rd edition. Preslia 84: 631-645.

Hennekens S.M., Schaminée J.H.J., 2001. Turboveg, a comprehensive data base management system for vegetation data. Journal of Vegetation Science 12: 589-591. DOI: $10.2307 / 3237010$.

Hollingsworth P.M., Squirrell J., Hollingsworth M.L., Richards A.J., Bateman R.M., 2006. Taxonomic complexity, conservation and recurrent origins of self-pollination in Epipactis (Orchidaceae). In Bailey J.P., Ellis R.G. (eds), Current taxonomic research on the British and European flora. Botanical Society of the British Isles, London, pp. 27-44.

Hrivnák R., 1997. Nové lokality druhov rodu Epipactis v južnej časti stredného Slovenska [A new localities of Epipactis-species in the southern part of Central Slovakia]. Bulletin Slovenskej Botanickej Spoločnosti 19: 119-122.

Janečková P., Wotavová K., Schödelbauerová I., Jersáková J., Kindlmann P., 2006. Relative effects of management and environmental conditions on performance and survival of populations of a terrestrial orchid, Dactylorhiza majalis. Biological Conservation 129: 40-49. DOI: 10.1016/j.biocon.2005.09.045.

Jakubska-Busse A., Dudkiewicz M., Jankowski P., Sikora R., 2009. Mathematical inference of the underground clonal growth of Epipactis helleborine (L.) Crantz (Or- chidaceae, Neottieae). Botanica Helvetica 119: 69-76. DOI: 10.1007/s00035-009-0057-1.

Jarolímek I., Šibík J., 2008. Diagnostic, constant and dominant species of the higher vegetation units of Slovakia. Veda, Bratislava, $332 \mathrm{p}$.

Jurčák J., Čuříková M., Látr A., 2005. The root anatomy and mycorrhiza of Epipactis pontica Taubenheim (Orchidaceae). Thaiszia - Journal of Botany 15: 11-30.

Jurčák J., Látr A., Čuř́iková M., 2006. Preliminary observation of fungal colonization in a rare orchid species (Epipactis pontica Taubenheim) in the Czech Republic. Thaiszia - Journal of Botany 16: 1-9.

Király G., 2007. Vörös Lista. A magyarországi edényes flóra veszélyeztetett fajai. Saját kiadás, Sopron, 73 pp.

Marhold K., Hindák F. (eds), 1998. Zoznam nižších a vyšších rastlín Slovenska [Checklist of non-vascular and vascular plants of Slovakia]. Veda, Bratislava, 688 p.

McCune B., Mefford M.I., 1999. PC-ORD. Multivariate analysis of ecological data, version 4.0. MjM Software Design, Gleneden Beach, Oregon, 237 p.

Mered'a P. jr., 1997. Príspevok k poznaniu Epipactis pontica Taubenheim na Slovensku [Contribution to the knowledge of Epipactis pontica Taubenheim in Slovakia]. Bulletin Slovenskej Botanickej Spoločnosti. 19: 122-128.

Miklós L. (ed.), 2002. Atlas krajiny Slovenskej republiky. 1. vydanie [Landscape Atlas of the Slovak Republic. First Edition]. MŽP SR, Bratislava and SAŽP, Banská Bystrica, $344 \mathrm{p}$.

Packham J.R., Thomas P.A., Atkinson M.D., Degen T., 2012. Biological flora of the British Isles: Fagus sylvatica. Journal of Ecology 100: 1557-1608. DOI: 10.1111/ j.1365-2745.2012.02017.x.

Perný M., Mered'a P., 2000. Príspevok k poznaniu vstavačovitých (Orchidaceae) Bielych Karpát (západné Slovensko) [Contribution to orchid flora (Orchidaceae) of the Biele Karpaty Mts (W Slovakia)]. Bulletin Slovenskej Botanickej Spoločnosti 22: 101-113.

Petrova A.S., Venkova D.Y., 2006. Epipactis pontica (Orchidaceae): a new species for the Bulgarian flora. Phytologia Balcanica 12: 249-253.

Presser H., 2002. Orchideen. Die Orchideen Mitteleuropas und der Alpen [Orchids. Orchids of Central Europe and the Alps]. Nikol Verlagsgesselschaft $\mathrm{mbH} \& \mathrm{Co}$, Hamburg, $374 \mathrm{p}$.

Rasmussen H.N., 1998. The underground phase: a special challenge in studies of terrestrial orchid populations. Botanical Journal of the Linnean Scoiety 126: 49-64. DOI: 10.1111/j.1095-8339.1998.tb02515.x.

Rasmussen H.N., Whigham D.F., 1993. Seed ecology of dust seeds in situ: a new study technique and its application in terrestrial orchids. American Journal of Botany 80: 1374-1378. DOI: 10.2307/2445665.

R Development Core Team, 2011. R: A language and environment for statistical computing. R Foundation for Statistical Computing, Vienna, Austria.

Silvertown J., Wells D.A., Gillman M., Dodd M.E., Robertson H., Lakhani K.H., 1994. Short-term effects and 
long-term after-effects of fertilizer application on the flowering population of green-winger orchid Orchis morio. Biological Conservation 69: 191-197. DOI: 10.1016/0006-3207(94)90059-0.

StatSoft, 2001. STATISTICA. System reference. StatSoft Inc., Tulsa.

Stuckey I.H., 1967. Environmental factors and the growth of native orchids. American Journal of Botany 54: 232241. DOI: $10.2307 / 2440803$.

Sulyok J., Molnár A., 2011. Pontuszi nőszőfü [Pontic Helleborine]. In: Molnár A. (ed.), Magyaország orchideáinak atlasza. Kossuth kiadó, pp. 265-266.

Špalková J., 2000. Zmeny lesných spoločenstiev Javorníkov (diplomová práca) [Plant community changes of the Javorníky Mts] Depon in BÚ SAV Bratislava. $61 \mathrm{p}$.

Taubenheim G., 1975. Epipactis pontica Taubenheim spec. nov. eine neue Stendelwurz aus Kleinasien [Epipactis pontica Taubenheim spec. nov., a new Helleborine from Asia Minor]. Die Orchidee 26: 68-74.

Taylor D.L., Bruns T.D., 1999. Population, habitat and genetic correlates of mycorrhizal specialization in the 'cheating' orchids Corallorhiza maculata and C. mertensiana. Molecular Ecology 8: 1719-1732. DOI: 10.1046/j.1365-294x.1999.00760.x.

ter Braak C.J.F., Šmilauer P., 2002. Canoco reference manual and CanoDraw for Windows user's guide. Software for canonical community ordination (version 4.5). Microcomputer Power. Ithaca, NY, $500 \mathrm{p}$.

Tichý L., 2002. Juice, software for vegetation classification. J. Veg. Sci. 13: 451-453. DOI: $10.1111 / \mathrm{j} .1654$ 1103.2002.tb02069.x.

Timpe W., Mrkvicka C., 1996. Beiträge zur Morphologie, Ökologie und Verbreitung von Epipactis nordeniorum, E. pontica und E. albensis in Südost-Österreich [Notes to morphology, ecology and distribution of Epipactis nordeniorum, E. pontica and E. albensis in Southeast Austria]. Florae Austriacae novitates 4: 1-10.

Tranchida-Lombardo V., Cafasso D., Cristaudo A., Cozzo- lino, S., 2011. Phylogeographic patterns, genetic affinities and morphological differentiation between Epipactis helleborine and related lineages in a Mediterranean glacial refugium. Annals of Botany 107: 427-436. DOI: 10.1093/aob/mcq256.

Tsiftsis S., Tsiripidis I., Karagiannakidou V., Alifragis D., 2008. Niche analysis and conservation of the orchids of east Macedonia (NE Greece). Acta Oecologica 33: 27-35. DOI: 10.1016/j.actao.2007.08.001.

Tyler G., 2003. Some ecophysiological and historical approaches to species richness and calcicole/calcifuge behaviour - contribution to a debate. Folia Geobotanica 38: 419-428. DOI: 10.1007/BF02803249.

Vallius E., 2001. Factors affecting fruit and seed production in Dactylorhiza maculata (Orchidaceae). Botanical Journal of the Linnean Society 135: 89-95. DOI: 10.1111/j.1095-8339.2001.tb01083.x.

Vlčko J., 1995. Epipactis pontica Taubenheim, a new species of the Slovak flora. Biológia 50: 329-330.

Vlčko J., 1996. Rod Epipactis na Slovensku (kandidátska dizertačná práca) [Epipactis in Slovakia]. Depon in Lesnícka fakulta TU Zvolen. $170 \mathrm{p}$.

Vlčko J., Dítě D., Kolník M., 2003. Orchids of Slovakia. ZO SZOPK Orchidea, Zvolen, 120 p.

\section{Supporting Information}

The online version of the article includes the Supp. Info.

List of sites with the occurrence of Epipactis pontica in Slovakia

Table 1. Basic geographic characteristics of the sampling sites 